\title{
A universidade na trajetória dos parlamentares brasileiros
}

Não é que ele terminou mesmo deputado? E obrigando os outros a chamarem-no de doutor. (Clarice Lispector, $A$ hora da Estrela)

A sobrerrepresentação de acadêmicos no mundo político é um fenômeno generalizado na maioria dos países com democracias estabelecidas ${ }^{1}$. Em certa medida, a determinação da eleição como um meio de construção da representação política reside, desde o início, em uma suposta meritocracia: quando os teóricos norte-americanos e europeus discutiram a emergência da República no final do século XVIII, não hesitaram em considerar que os governantes deveriam ser a expressão "do melhor do corpo social", "os mais capazes de exercer o governo". Claramente, como sustentam os escritos de James Madison (1961), o objetivo foi estabelecer um governo republicano, descartando as alternativas igualitárias, que propunham que os representantes fossem cidadãos comuns.

Este ponto de partida tem forte influencia na história da democracia representativa moderna. Os representantes políticos que emergem do escrutínio - que funciona como uma seleção -compõem um universo diferente dos cidadãos/eleitores. É esta diferença que tem sido desenvolvida em muitos dos estudos das elites políticas, que participam do processo de revitalização na ciência política nas últimas duas décadas (Genieys, 2006).

A diferença entre o "pessoal político", atuando como representante, e os cidadãos, é construída sobre a capacidade dos primeiros a passar com

\footnotetext{
Professor de Ciência Política da Universidade de Buenos Aires (Buenos Aires, Argentina). E-mail: unzuemart@yahoo.com

Tradução do espanhol: Mariana Matulana. Agradeço também os comentários de Rita Lages. 
sucesso por meio de um processo eleitoral, existindo muitos fatores complexos envolvidos na produção dessa elegibilidade. Destaca-se cada vez mais significativa a capacidade de acesso aos recursos necessários para financiar o desenvolvimento de campanhas cada vez mais caras.

Tal requisito ameaça muitas de nossas democracias representativas atuais, com uma mutação plutocrática que parece dificilmente compatível com a sua legitimação, baseada na ideia da igualdade política, e até mesmo com o persistente sentido etimológico da palavra democracia.

Isto significa que a exclusão das maiorias do governo não pode ser justificada pela sua incapacidade econômica para enfrentar uma campanha eleitoral, embora ela seja uma verdadeira limitação. Só um relato das capacidades, isto é, estruturado na suposição de que aqueles que são eleitos por todos são os "melhores", parece encontrar uma maneira de compatibilidade entre o ideal de democracia e a representação política. O povo elegeria os seus melhores homens para o governo, tendo como consequência a suposta afinidade entre a ideia de democracia e um governo nas mãos de poucos (os representantes).

Nesse contexto, torna-se relevante a universidade como uma instituição à qual as sociedades modernas têm atribuído o papel fundamental de produzir, transmitir e certificar a posse de seu maior conhecimento, um processo que culmina com a atribuição de graus acadêmicos, que, como bem indica Pierre Bourdieu (1989), são as principais formas de distinção que ainda subsistem.

Assim, a aquisição do capital simbólico que os representantes precisam para se validar eleitoralmente tem, no prestígio e no reconhecimento de diplomas universitários, uma fonte recorrente, como será apresentado no presente artigo, pela análise do caso do Congresso brasileiro.

A compatibilidade da notoriedade pela posse de diplomas universitários com o princípio democrático reside na presunção da capacidade e no caráter tendencial de tal discriminação que anula as alegações potenciais de conservadorismo oligárquico. Quanto à alegada existência do mérito como a única condição para a admissão ao diploma, pode-se argumentar, falsamente, pela ausência de impedimentos outros além da capacidade para o acesso ao ensino superior.

Consequentemente, o valor social do diploma universitário como fator distintivo torna-se um elemento importante na formação do capital político necessário para otimizar as chances de sucesso na competição eleitoral. Não é um requisito formal, nem obrigatório. Como é possível ver no caso 
da chegada de Lula da Silva na Presidência da República, há maneiras de preencher essa lacuna (voltaremos logo sobre esse ponto).

Mas a valorização do diploma universitário existe, é positiva e crescente, pois considera-se que nem todos podem ser universitários, que a universidade é uma instituição seletiva, e que os eleitores confiam na sua eficácia para a discriminação de capacidades e transferência de conhecimentos valiosos, todas condições, como veremos, presentes nos discursos dos deputados e senadores.

Também podemos constatar a possibilidade de transformar o capital simbólico acumulado no campo da universidade em capital simbólico político, quando o prestígio social da academia é maior.

Apesar da importância de se ter em conta uma história da universidade no Brasil, incluindo as formas tradicionais de restrições ao seu ingresso, bem como a percepção política e estatal da mesma, tais objetivos espacam ao âmbito do presente estudo.

Assim, como veremos na própria voz do Congresso, o pertencimento à universidade, à burguesia e ao governo parecem gerar mecanismos de solidariedade e de identificação. A universidade brasileira, mesmo em um processo de expansão, continua a funcionar muito longe das maiorias e, em grande parte, ela produz um modo de distinção compatível com as hierarquias sociais.

A contribuição das credenciais acadêmicas para a imagem dos candidatos é um elemento importante para otimizar suas chances de desenvolvimento eleitoral, bem como os seus percursos no campo da política. A posse deste suposto saber ${ }^{2}$, que é simbolizado em títulos universitários como elemento de distinção, admite - e isso surpreendentemente permanece apesar do processo de expansão do acesso a esses diplomas - uma forma de equivalência entre o título e uma notoriedade que se torna valiosa.

Como opera a universidade nesse processo? Não podemos esquecer, embora não vamos desenvolvê-las, algumas questões-chave sobre o papel da universidade como um campo de recrutamento para os quadros políticos, ou como campo de socialização política. A organização política estudantil nas universidades é uma zona de passagem para alguns quadros políticos, e isso é frequentemente referido pelos parlamentares.

Nota-se aqui que o problema não é o conhecimento, mas a suposição de sua posse, cristalizada no credencial conferido pelo diploma. Vale ressaltar que não estamos afirmando que as elites políticas são elites intelectuais. 
Mas a relação entre conhecimento e política no mundo dos representantes, dos políticos profissionais, vai além disso: supõe uma universidade que oferece um suporte, uma distinção, mesmo um discurso. Os universitários apresentam uma capacidade deliberativa, mas não atribuindo ao termo o sentido dado pelos teóricos da democracia deliberativa. Não há dúvida de que a deliberação desempenha um papel fundamental no mundo político, mas é preciso esclarecer o que se entende por deliberação. Jon Elster (1994) faz uma distinção importante para analisar este ponto: ele distingue argumentação de negociação. A deliberação política não é o que vem do sentido franco do termo, não é a deliberação como argumento racional, que visa à imposição do melhor argumento sobre os mais fracos ou os menos informados. A discussão dada, por exemplo, no parlamento, não pretende o convencimento de outro (apenas de forma limitada e marginal). $\mathrm{O}$ apelo ao conhecimento não é para convencer, mas para legitimar uma posição, e esta é uma conclusão clara de nossa análise.

A deliberação predominante no mundo político é aquela que produz a negociação. Portanto, a deliberação existe não tanto como persuasão, mas como negociação.

Neste ponto, a universidade oferece muitas ferramentas: o discurso, a retórica, mas principalmente a autoridade e a habilitação para falar. A universidade autoriza a entrar na deliberação, no diálogo como negociação, sob uma perspectiva de igualdade. Portanto, ela abre as portas para um jogo discursivo, mas também gera uma condição fundamental para a deliberação: o reconhecimento do outro. Porque a negociação requer pares em algum sentido. Sem pares não existe negociação, somente imposição.

Então, o papel da universidade é compreendido plenamente no jogo da política deliberativa, porque, em primeiro lugar, é um elemento habilitante para ingressar nesse jogo. Pois, para falar sobre determinados assuntos no mundo político, deve-se pertencer ao mundo da universidade. Isso contribui para a explicação da "sobrerrepresentação" de universitários no campo político, que é um poderoso elemento de "discriminação suave" no acesso ao governo. Tanto os deputados quanto os senadores fazem constantes referências à relevância de sua formação universitária.

Segundo estimativas do Instituto Brasileiro de Geografia e Estatística (IBGE), entre 7 e $8 \%$ da população acima de 25 anos completaram os estudos universitários. A análise da composição da legislatura para o ano de 
2006 (não muito diferente da atual), confirma a sobrerrepresentação muito forte dos universitários. Pelo menos 77,5\% dos 80 senadores e $71 \%$ dos 513 deputados declararam ter concluído a faculdade 3 .

A outra observação que podemos fazer é que a Câmara Alta mostra "mais universitários" que a Câmara dos Deputados, que corresponde, em certa medida, ao papel que desde o início do bicameralismo tem sido dado ao Senado, visto como o âmbito de representação dos estados e não diretamente do povo. Se o Senado foi concebido como um lugar onde as paixões do povo poderiam ser contidas, o peso dessa tradição parece continuar a existir ${ }^{4}$. Lembremos as conclusões de Alexis de Tocqueville sobre o Senado dos Estados Unidos, ao ponderar sobre a forma indireta de eleição de seus membros:

Mas basta que a vontade popular passe através dessa assembleia escolhida para, de certa forma, nela se elaborar e dela sair revestida de formas mais nobres e mais belas. Os homens assim eleitos (os senadores) representam, pois, sempre exatamente, a maioria da nação que governa; mas representam tão somente os pensamentos elevados que lá circulam, os instintos generosos que a animam, e não as pequenas paixões que muitas vezes agitam-na e os vícios que a desonram (Tocqueville, 1986, p. 305).

Um século e meio mais tarde, os senadores ainda são, tendencialmente, procedentes de classes sociais mais altas e universitárias em geral.

A análise do Congresso brasileiro também permite confirmar que, à medida que subimos nas estruturas hierárquicas do parlamento, a proporção de universitários aumenta. No Senado, em 2006, 91,67\% dos líderes dos blocos partidários possuíam diplomas universitários (contra 8,33\% não diplomados), $88,89 \%$ dos presidentes das comissões permanentes eram universitários ( $11,11 \%$ não-universitário ) e $85,71 \%$ das autoridades do Senado passaram pela universidade $(14,29 \% \text { não universitários })^{5}$. Novamente, observamos

Todos os dados incluídos nesta seção sobre a formação universitária dos deputados e senadores foram coletados de pesquisa realizada em registros públicos apresentados pelos sites oficiais do Senado e da Câmara, assim como nas páginas web pessoais dos congressitas, em 2006.

4 A definição da palavra "senado" tem como primeira acepção: "corpo legislativo composto por pessoas eleitas ou nomeadas em virtude de sua qualificação, título ou posição, etc ...". A voz "Senado" vem do latim "sen" e este do germânico "sinn", e é um adjetivo que significa sensível, sensato.

Foram considerados doze blocos partidários, nove comissões permanentes e como autoridades do Senado o presidente, os dois vice-presidentes e os quatro secretários. 
que a elite dos representantes tem uma participação universitária superior à média registrada no corpo legislativo ${ }^{6}$.

$\mathrm{Na}$ Câmara dos Deputados, os dados que foram coletados mostram que 85\% dos líderes dos blocos partidários são universitários, assim como 80\% dos presidentes das comissões e $71 \%$ das autoridades da Casa ${ }^{7}$.

Quanto às profissões universitárias, a análise disciplinar da natureza dos representantes brasileiros (incluindo senadores e deputados) mostra que predomina a advocacia, o que reproduz uma tradição verificável na maior parte do mundo (exceto o Japão) ${ }^{8}$.

Em nossa pesquisa, temos notado também que o número de representantes que têm mais de um título da faculdade é maior que o encontrado em outros parlamentos dos países da região. Marcante foi o número de parlamentares que afirmaram ter obtido um diploma universitário enquanto atuavam como parlamentares, bem como o daqueles que afirmaram estar seguindo ou terem iniciado seus estudos universitários em paralelo com as suas funções legislativas. Entre os que se declararam não universitários, um número muito elevado expressou ter estudos universitários incompletos (em 2006, nada menos que 43,69\% dos deputados que se declarou não universitário afirmaram no seu currículo ter passado pela universidade em algum momento ${ }^{9}$ ).

Podemos também identificar que existe certo prestígio associado ao papel de professor universitário, como o clímax da valorização dos conhecimentos profissionais: $11,25 \%$ dos senadores e $12,67 \%$ dos deputados mencionaram

6 Embora aqui devemos distinguir uma diferença sutil entre a sobrerrepresentação geral dos universitários no Congresso, que se deve tanto à forma como eles constroem seu capital simbólico perante os cidadãos eleitores, como ao papel da etapa universitária para as elites partidárias (seu peso na consagração das candidaturas), da questão da sobrerrepresentação dos universitários entre as autoridades do poder legislativo, que é devido, principalmente, ao segundo tipo de explicação relacionada ao problema da ordem e às hierarquias internas nas elites políticas.

Foram considerados os quatorze blocos partidários, as trinta comissões permanentes e todas as autoridades da Casa (presidente, vice-presidentes e secretários).

8 Os trabalhos sobre o papel dos advogados na política são numerosos. Começamos com as considerações de Max Weber em A política como profissão, seguindo o livro e Eulau e Srague (1964), dedicado aos advogados nos Estados Unidos da América, ou os trabalhos de Imaz (1964) ou Molinelli, Palanza e Sin (1999), referindo-se ao caso argentino. A excepção parece ser o Japão, em que apenas 5\% dos parlamentares são advogados, de acordo com Fukai e Fukui (1992) apud Uriarte (1997). Isso se daria, de acordo com os autores, devido ao baixo número de advogados na sociedade japonesa. No caso do Brasil, ver Lemos e Ranincheski (2003).

9 Os diferentes mecanismos para o ingresso na universidade são também um fator a ter em conta para compreender o valor que parece ser atribuído à educação universitária, mesmo realizada de forma incompleta, o que não é encontrado em outros casos, como o argentino, em que a realização incompleta de uma educação universitária pode parecer mais uma fraqueza que uma virtude. 
esse antecedente dentro de suas ocupações presentes ou passadas e 17,5\% dos senadores e $22,61 \%$ dos deputados declaram ter realizado estudos de pós-graduação. ${ }^{10}$ Tudo isso mostra que as fronteiras entre academia e parlamento são porosas, e que através deles ocorre um intenso trânsito em mão dupla, que se manifesta não apenas em trajetórias pessoais, mas também em discursos, eventos, prêmios e participações compartilhadas entre outros eventos.

\section{Como se referem à universidade os parlamentares no Congresso Federal?}

O trabalho que se segue é uma análise do conjunto de discursos de senadores e deputados do Congresso federal em sessões plenárias de cada casa, feitas ao longo do ano de 2006, tomados tanto das versões taquigráficas quanto de materiais audiovisuais.

Esta análise procura mostrar como os parlamentares se relacionam com a universidade e que usos fazem dela no parlamento. Para tanto, estudamos os discursos dos senadores brasileiros em 45 sessões plenárias (num total de 205 realizadas no ano em análise), selecionadas de forma aleatória. $\mathrm{O}$ mesmo foi realizado com 99 sessões da Câmara dos Deputados, também escolhidas de forma aleatória de um total de 209 registradas no ano de 2006 (que inclui 48 sessões de discussão, 77 sessões especiais, 64 sessões ordinárias e 20 sessões "solenes", isto é, as sessões de homenagem $)^{11}$.

Como a frequência de temas relacionados com a "universidade" tem sido elevada, tornando-os uma espécie de presença espectral alimentada pelas vozes dos parlamentares que costumam invocá-la de formas diversas e com múltiplos fins, no restante deste artigo, tentaremos classificar e agrupar esses modos de abordagem, dando exemplos emersos dos discursos, a fim de fornecer novos elementos para dimensionar a ligação entre o mundo político e a universidade.

10 Por uma questão de espaço não desenvolverei aqui a relação entre as formas de recrutamento e os partidos políticos. Um encaminhamento para os casos de Brasil, Chile e Uruguai pode ser encontrado no trabalho de Marenco e Serna (2007).

11 As sessões analisadas são resultado de uma amostra aleatória simples, sem reposição e partiu da definição do total de sessões de 2006 para cada casa, tomando-se as versões taquigráficas registradas nas páginas oficiais. Foi determinado certo número de sessões e em seguida procedeu-se à escolha ao acaso de uma sessão. Como o trabalho buscava constatar a presença do tema "universidade" nos discursos dos representantes, devemos notar que em cada sessão analisada foram revisados todos os discursos pronunciados. Em uma sessão ordinária, é frequente encontrar entre 15 e 25 oradores inscritos ao que se somam os intercâmbios verbais imprevistos. Desse modo, o corpo de intervenções analisadas foi considerado suficiente para tornar a amostra representativa. 
Do trabalho feito com a grande quantidade de discursos recuperados, identificamos em princípio 30 tipos de argumentos, com vários exemplos de cada um, em que os representantes se referem à universidade. Por razões de espaço neste artigo, selecionamos algumas destas categorias, priorizando as mais importantes, tanto pela riqueza do material apresentado, como pela sua importância à luz do problema em análise $\mathrm{e}^{12}$.

\section{A distinção nos discursos dos representantes federais}

A primeira coisa fácil de destacar nos discursos dos congressistas é que certas práticas do protocolo têm sido mantidas. Como exemplo, o tratamento dos senadores está repleta de termos como "Vossa Excelência", "nobre senador" e similares, que representam uma utilização generalizada de maneiras corteses para enfatizar a importância da condição de senador, visto que sublinha a distinção que significa integrar essa câmara, que pode ser tomado como uma indicação de um certo esprit de corps.

Nesse ponto, consideramos válidas as observações de Marc Abélès quando explica, referindo-se ao caso francês, que todos os representantes compartilham uma "consciência de respeitabilidade" e de "destaque", que é reforçada pelo contato diário entre os pares, que não apenas compartilham o mesmo espaço, senão que possuem uma série de experiências comuns que incluem ter passado (com sucesso) por uma campanha eleitoral, até participar de múltiplos privilégios vinculados a sua posição - que são destacados dentro do Congresso, a partir do tratamento do pessoal e da possibilidade de livre acesso a lugares que nem todos podem ingressar ${ }^{13}$, mas que se reflete também na obtenção de certos benefícios materiais e simbólicos de sua própria posição ${ }^{14}$ (Abélès, 2001, p. 102 e ss.). No caso dos congressistas brasileiros, que em muitos casos tendem a renovar seus mandatos, há também a per-

2 Lembre-se que o presente artigo é uma pequena apresentação de um trabalho maior. A seleção de certos tipos de argumentos que fizemos aqui é baseada na repetição e na presença em ambas as câmaras do Congresso, para exemplificar.

13 É comum a existência de estacionamento, elevadores e outras áreas dedicadas aos representantes, o acesso privilegiado às bibliotecas e documentos, em alguns casos salões exclusivos e uma prioridade geral de dispor do espaço comum do Congresso.

14 Não é por acaso que, enquanto reconhecemos que não há homogeneidade entre os representantes em nenhum parlamento, e que embora os parlamentares possam ser uma espécie de "tribo", que compartilha muitas práticas, métodos e horários, também são claros os clãs em que se dividem, cada um com suas crenças e rituais que os distinguem, o que nos levou a considerar o termo "elites" no plural. Por outro lado, devemos notar a contradição de Abélès quando sustenta que os representantes são cidadãos comuns e, ao mesmo tempo, lhes reconhece a posse de códigos compartilhados de notabilidade. 
cepção criada por vários anos de trabalho conjunto. Assim, nos discursos, há muitas evidências de um sentimento de pertencimento a um lugar de poder relevante e significativo.

Nesse sentido, na intervenção produzida na muito interessante sessão de 17 de janeiro de 2006, encontramos um senador que se refere ao Senado nestes termos: "Sr. Presidente, meu caro Senador Ramez Tebet, como todos sabem, esta Casa é composta de grandes valores nacionais e abriga mais de 40 ex-Governadores, grandes advogados, médicos, economistas e tantos outros."

O apelo à "Casa”, uma expressão comum referindo-se ao Congresso, é um modo inequívoco de assinalar pertencimento e familiaridade com um corpo que não hesita em destacar o valor dos seus membros, autoconsiderados, nas palavras do senador citado, "grandes valores nacionais". É sugestivo ver que a lista é formada, após os governadores, pelos universitários, advogados, médicos, economistas ... esses são "os grandes homens" que conformam o Senado.

Nesse sentido, esses grandes homens merecem grandes reconhecimentos. Talvez por essa razão, o Congresso gosta muito de auto-homenagens.

É na mesma sessão de 17 de janeiro que ocorre a entrega do diploma de Doutor Honoris Causa a um senador, pela UNILEGIS, a Universidade do Poder Legislativo Brasileiro, que, pela primeira vez, outorgava essa distinção simbólica para honrar ao seu fundador.

Um grande número de intervenções nessa sessão estão destinadas a parabenizar e celebrar a grandeza do senador que recebeu o doutorado honorário, e que não perdeu a ocasião para destacar a importância de que exista uma universidade funcionando dentro do parlamento (que não duvidam em qualificar como a "a primeira universidade do Legislativo no mundo"). Outro senador, na mesma sessão, assegura:

Eu não poderia deixar de vir ao plenário para manifestar, neste momento, o meu apoio - fiz questão de assinar essa proposição - à feliz escolha dos servidores, dos profissionais e dos técnicos da Unilegis, bem como de todos aqueles que constroem essa instituição tão importante para o Parlamento brasileiro, para oferecer esse título tão nobre que é a condição de doutor honoris causa. A universidade é uma instituição que existe há 900 anos e é nela, que vem do princípio da universalidade, que a Humanidade deposita o seu conhecimento, de geração em geração. Em todas as áreas do conhecimento, na interdisciplinaridade, no pluralismo das idéias, nas diversas correntes do pensamento, a universidade é a depositária do saber que a Humanidade vai acumulando ao longo de sua história. A Unilegis é a instituição brasileira em que 
depositamos a parte mais importante do conhecimento que o Parlamento consegue construir. Por meio dela, podemos formar novos quadros de dirigentes e servidores que aprimorarem o Parlamento.

Nessa passagem acima transcrita, podemos destacar várias itens: primeiro, a importância atribuída não só ao título, mas também à universidade, apresentada como o repositório de conhecimento que a humanidade constrói na sua história e também como uma instância essencial para formar os "novos líderes”. O valor da universidade não é discutido, como veremos a seguir e, neste sentido, a própria existência da Unilegis não pode deixar de ser vista à luz de uma sociedade que reconhece à universidade um lugar de destaque, a ponto de ter que associar não só o Parlamento com as universidades existentes, mas com a sua própria universidade ${ }^{15}$.

Em grande medida, a relevância da passagem pela universidade está relacionada com a aceitação da importância do conhecimento como instância legitimadora, como podemos ler nessa outra intervenção produzida na mesma sessão quando um senador diz: "V. Exª, sobremodo pela sabedoria, pelo conhecimento, pela erudição, pelo preparo reconhecido por todos, destaca-se no cenário nacional". Esses elogios passam exclusivamente pelo saber (sabedoria, conhecimento, aprendizagem, preparação), argumentando que isso é o que faz se destacar no cenário nacional.

Fica claro que, no senso comum, expresso em muitos dos discursos dos senadores, há uma relação íntima entre o conhecimento que produz admiração e que ocupa um lugar de destaque na sociedade (como o cargo de senador). Sem dúvida, nesse sentido, a posse de conhecimento é vista como relevante para o acesso ao Senado nas eleições.

\section{A valoração da universidade por parte dos congressistas}

Os discursos feitos no Senado e na Câmara mostram que há um reconhecimento importante, com poucas nuanças, das universidades, especialmente das estatais (e, mais particularmente, as federais, exceto no caso das estaduais de São Paulo), bem como de seus professores, pesquisadores e doutores, que se expressa de forma constante nas expressões de orgulho dessas instituições.

Lembre-se que a Unilegis foi criada em 2001 para oferecer cursos de pós-graduação (especialização), geralmente em parceria com outras universidades federais e desenvolver tarefas destinadas a profissionalizar o pessoal do Congresso, em particular através de seminários, conferências e cursos de curta duração. 
Podemos citar a intervenção de um senador na sessão de 20 de janeiro: "Preparei um pronunciamento a respeito das universidades do Brasil, mais precisamente das boas coisas que ocorreram no ensino universitário durante os últimos anos".

Por ocasião do debate em 30 de janeiro, outro senador argumentou: "Nas universidades públicas sempre estiveram - e ainda estão - as mais prestigiadas instituições de ensino e extensão do Brasil, bem como os nossos principais centros de excelência em pesquisa e desenvolvimento tecnológico". $\mathrm{Na}$ mesma sessão, outro senador disse, ainda:

Essa base de ciência e tecnologia e essas universidades que concentram boa parte da pesquisa de ponta, como USP, Unicamp, Unesp, poderiam estimular um amplo programa de inovações científico-tecnológicas e trazer investimentos. (...) poderíamos ter criado, já há muito tempo, no Brasil, particularmente em São Paulo, um novo Vale do Silício.

Um terceiro exemplo, também de 30 de janeiro, surge a partir da intervenção de um senador do estado do Piauí: "Há aquele triângulo: São José dos Campos aqui, Campinas ali, São Carlos acolá, a USP, as universidades. Enfim, São Paulo faz pesquisas de primeiro mundo; não há dúvida. Agora, por exemplo, há uma pesquisa na USP que está revolucionando a cabeça de todo mundo...".

Na sessão de 21 de Fevereiro encontramos também uma intervenção que apela para a qualidade da universidade, há inclusive referência a uma instituição pequena e periférica. Um senador diz que "a Universidade Estadual de Maringá, que, aliás, é uma universidade pública da mais alta qualidade, desponta, num conjunto de cursos e de pesquisas, com um trabalho de extensão muito bom".

Estas intervenções mostram que vários senadores argumentam que existe excelência nas universidades, prestígio, pesquisa de ponta com qualidade inquestionável e, portanto, a universidade é considerada repetidamente como um ator para ser consultado, um ator sério e relevante para fornecer conhecimentos para a tomada de decisão.

A mesma conclusão emerge da leitura dos discursos dos deputados. Exemplos decorrentes da reunião de 7 de março, quando um legislador refere-se à expansão da UNICAMP, afirmando: 
A minha querida cidade de Limeira está em festa. Domingo passado o Governador Geraldo Alckmin e o magnífico Reitor da UNICAMP, Prof. Dr. José Tadeu Jorge, lançou em Limeira a pedra fundamental do campus de uma das maiores e melhores universidades do mundo, a menina dos olhos de São Paulo e orgulho dos brasileiros: a UNICAMP. Que cidade não gostaria de ter esse privilégio? Estiveram presentes ao lançamento vários Prefeitos da região, Vereadores, Deputados Federais e Estaduais, Secretários Estaduais e Municipais, professores, funcionários e populares. (...) teve o apoio incondicional do grande, do maior, do respeitável Magnífico Reitor da UNICAMP, Prof. Dr. José Tadeu Jorge (...).

Esta intervenção não hesitou em descrever a UNICAMP como uma das maiores e melhores universidades do mundo, o orgulho de todos os brasileiros, destacando o peso de seu reitor em termos exagerados, cheios de respeito e reconhecimento. Também, pode-se destacar, para medir o impacto político de uma ampliação da universidade, a longa lista de funcionários envolvidos no ato.

Outro deputado do mesmo estado, novamente refere-se às universidades da região, na reunião de 17 de abril, declarando: "Em meu Estado, as universidades estaduais são de ponta e desenvolvem pesquisa necessária à educação. Sem dúvida alguma, USP e UNICAMP são conhecidas nacional e internacionalmente e levam o nome de São Paulo para o mundo científico”.

Como vimos com os senadores, o reconhecimento dos deputados das universidades também se estende a outras instituições mais novas ou menores. Na sessão de 10 de maio, um deputado refere-se à Universidade de Roraima nos seguintes termos:

Assomo à tribuna para fazer uma breve homenagem à Universidade Federal de Roraima, a primeira a instalar-se no Estado. Considerada uma das mais jovens instituições federais de ensino superior no Brasil, tem um valor estratégico importantíssimo para a Amazônia e para o Brasil. Hoje, completados seus 16 anos, a instituição prova a cada dia que vem produzindo e disseminando conhecimentos e trabalhando na busca contínua de padrões de excelência e relevância no ensino, na pesquisa e na extensão. (...) o Reitor, Dr. Roberto Ramos, tem demonstrado capacidade administrativa e intelectual para conduzir os trabalhos. (...) tenho orgulho em assomar a esta tribuna para relatar o trabalho que vem sendo desenvolvido pela nossa universidade.

Algo semelhante acontece em 8 de junho, quando outro representante se refere à Universidade Federal do Paraná: 
Na condição de Parlamentar paranaense, que sempre lutou para oferecer à Universidade Federal do Estado os recursos e condições para que ela pudesse cumprir a importantíssima missão que lhe cabe, queremos deixar de público nosso voto de louvor e congratulações à administração do reitor Carlos Augusto Moreira Júnior bem como aos médicos e profissionais de todas as áreas da Ciência -, cujo trabalho tem sido fundamental no sentido de prover essa instituição, que tanto orgulha os paranaenses, dos meios para que ela continue avançando e se consolide como um espaço de excelência científica, de difusão do conhecimento e da capacitação com responsabilidade social e sentimento de justiça.

É evidente, a partir das intervenções selecionadas, que a universidade e suas autoridades (com destaque para a referência recorrente ao papel dos reitores) são uma fonte de orgulho e reconhecimento para os membros do Congresso e, na sua visão, para a sociedade. A universidade é apresentada como uma instituição de prestígio e, portanto, que confere prestígio, o que também ocorre na arena política, com a associação entre conhecimento e política.

Não se pretende, com a afirmação anterior, negar os jogos internos entre as elites políticas, em que os deputados e senadores no Congresso federal produzem sinais destinados a suas "pátrias pequenas". Daí desprende-se a existência de laços comuns entre as elites territorialmente governantes, as autoridades nas universidades e os congressistas. No entanto, a comparação com os discursos de parlamentares de outros países, como a Argentina, mostra que o elogio à universidade brasileira é uma figura distintiva. Caso não tivesse relevância o mito da universidade, se a dimensão ideológica não operasse no sentido de reconhecer as universidades como âmbitos de prestígio socialmente aceitos, como espaços de produção de conhecimentos reconhecidos positivamente, estes jogos não teriam eficácia.

Nesse sentido, podemos observar, no discurso de um deputado na reunião do 16 de janeiro, as referências à ligação cidadania-educação:

Nascemos na mata e não sabemos de nada. Graças a Deus, fui estudar na cidade. (...) não posso deixar de dizer que considero a compra de voto o maior crime da democracia. Se fosse algo normal, aqueles que apreciam dar dinheiro a um cidadão no dia da eleição comprariam o voto de um professor ou de uma pessoa considerada mais esclarecida pela sociedade (...). Quando alguém compra o voto do seu vizinho, também está afrontando aqueles que não vendem o seu voto. Portanto, defendo a 
democracia, porque quero que outros Chicões, filhos de uma lavadeira e de um seringueiro, venham ao Congresso Nacional dizer: estou aqui para representar o meu povo. Sofri muito para chegar aqui! Juízes ou pessoas importantes na nossa sociedade devem ajudar a colocar o País no rumo certo.

Nesse trecho selecionado, destaca-se a figura do professor como um iluminado (é verdade que pode não se referir exclusivamente ao professor universitário, porém se potencializa nesse caso), e apela a uma continuidade virtuosa entre o conhecimento e a qualidade da cidadania, que, curiosamente, são postas de lado considerações de ordem econômica ${ }^{16}$.

\section{A importância política do reconhecimento universitário}

$\mathrm{O}$ reconhecimento que a universidade tem, o elevado capital social da instituição, pode ser transmitido aos representantes (sempre ansiosos para aumentar a sua boa imagem) sob certas circunstâncias. Assim, podem existir formas de transferência previsíveis e frequentes quando o representante é um graduado de uma universidade, ou atuou como professor e relata a experiência em seus discursos. Encontramos também casos específicos em que representantes demandam explicitamente parte do prestígio da universidade em troca de apoio político, em uma espécie de transação que, paradoxalmente, sendo reconhecida como uma troca de favores, corre o risco de se desgradar e perder efetividade.

Na sessão de 13 de fevereiro, um senador do estado de Tocantins faz um longo discurso que reproduzimos em parte:

Nós, Congressistas, vivemos um momento de muita falta de credibilidade e de ataques. Por que faço essa colocação na fase inicial da minha fala? Exatamente para dizer que hoje, (...) no campus da Universidade Federal do Tocantins, a nossa Bancada Federal que tem assento na Câmara dos Deputados e no Senado Federal, portanto os três

\footnotetext{
${ }^{6}$ O deputado não diz que se o cidadão fosse rico não iria vender o seu voto, ou que vende o seu voto porque ele tem que comer. Ele argumenta que vende seu voto porque ele é ignorante, então um professor, ou alguém educado, não seria passível de realizar tal prática. Há uma extensa literatura sobre compra de votos e clientelismo na América Latina, como problema muitas vezes associada à pobreza. Neste sentido, pode-se ver Schedler (2004). Embora a conclusão é que a compra de votos entre os trabalhadores agrícolas mexicanos está se tornando menos efetiva, o trabalho não hesita em afirmar que "o clientelismo eleitoral com frequência dá por facto que os eleitores pobres são vítimas fáceis da compra de votos". Curiosamente, no caso do deputado brasileiro citado, a questão da pobreza não tem lugar diante da ignorância no que se refere às causas dessa prática.
} 
Senadores (...) e os oito Deputados Federais, foi homenageada pela Universidade Federal do Tocantins. Talvez um fato inédito no Brasil. E por que fomos homenageados? Fomos homenageados pelo Conselho Universitário do Estado do Tocantins, da Universidade Federal do Tocantins (...), a quem cumprimento neste momento por esta atitude simpática e correta, porque a Bancada Federal do Tocantins tem trabalhado diuturnamente no sentido de fortalecer a educação e o ensino superior no Estado do Tocantins (...). E, na homenagem de hoje, recebemos uma medalha de Honra ao Mérito - por sinal uma medalha muito bonita -, em uma solenidade de alto nível. Nos últimos dois anos, Sr. Presidente Mão Santa, a nossa Bancada conseguiu colocar no caixa da Universidade Federal do Tocantins, por intermédio de emendas de Bancada e de emendas individuais deste Parlamentar e de vários outros, recursos da ordem de $\mathrm{R} \$ 10,620$ milhões (...) é claro que todos ficamos orgulhosos. (...) os universitários do Tocantins foram extremamente inteligentes, porque conquistaram, cada vez mais, o coração da sua Bancada. Deixaram-nos sensibilizados. Foram eficientes nessa homenagem simples, mas de grande significado. Ela representou muito para nós. V. Exa , que é médico, sabe o quanto é difícil, no meio universitário, a participação e a presença dos políticos (...). Creio que esse exemplo, Sr. Presidente, deveria ser seguido por todas as universidades federais do Brasil.

O discurso parte do reconhecimento de que os representantes políticos não usufruem de muito prestígio. As razões são muitas. A crise da representação política conhece certos embates particulares, que aprofundam a necessidade de legitimidade do parlamento brasileiro. Esta situação seria agravada por uma circunstância em que vários membros do Congresso estavam envolvidos em uma série de casos de corrupção, muito difundidos pelos meios de comunicação ${ }^{17}$. Nesse contexto, a necessidade de legitimação, a partir de um reconhecimento da universidade, é reforçada. Dessa forma, é interessante notar que o senador mostra o reconhecimento que recebem como um ato de troca, no qual a universidade "tem sido muito inteligente" para reconhecê-los, sabendo que eles têm muito a ganhar (a biblioteca hoje, as obras amanhã), mas ao mesmo tempo, ciente disso, os representantes aceitaram a distinção, a fim de capitalizá-la, sugerindo ainda que todas as universidades federais deveriam fazer o mesmo: proporcionar o reconhecimento e o prestígio aos legisladores em troca de recursos orçamentais.

17 A sombra do que foi chamado o escândalo do "mensalão" não deixa de estar presente de forma constante nos discursos dos deputados. 


\section{A universidade e a formação universitária}

É frequente encontrar nas duas câmaras referências às vidas universitárias dos parlamentares e a sua condição de universitários. Um exemplo é manifesto na intervenção feita por uma senadora na sessão de 19 de janeiro:

Eu trabalhei durante toda a minha vida na Universidade, na área de Planejamento de Serviços Públicos. Então, eu sei exatamente o que é o planejamento dos serviços públicos, o que significa identificar e fazer o diagnóstico situacional, analisar os indicadores sociais, analisar a infraestrutura, os serviços a serem disponibilizados (...). Então, eu me sinto muito à vontade para planejar a elaboração das minhas emendas, especialmente as minhas emendas individuais, à luz de todo o conhecimento técnico que, por obrigação, como professora da Universidade, eu acumulei ao longo da minha história de vida.

A senadora lembra que ela sempre trabalhou na universidade, que ela ensinou, e que isso lhe deu habilidades técnicas que lhe permitem exercer o seu trabalho parlamentar (referindo-se especificamente a propor emendas).

Outra senadora também disse, na mesma reunião: "Fui professora por mais de 20 anos na Universidade Federal de Mato Grosso, como o Senador Gilvam Borges já disse, e sei da importância da educação”. Novamente, o argumento de ser um professor universitário é usado para afirmar uma posição ou tema de responsabilidade. A mesma senadora, numa sessão posterior (3 de fevereiro), referindo-se a uma série de conflitos trabalhistas importantes que estavam acontecendo em universidades públicas, retoma a sua condição de professora universitária, alegando que, na realidade, essa é a sua identidade original e permanente mesmo acima da de senador:

Senadores, vamos tratar hoje aqui de uma questão que estava nos preocupando, relacionada aos professores universitários. Saímos - digo saímos, porque sou professora universitária; estou Senadora - há poucos dias, professores e professoras, de uma greve de mais de 100 dias (...). A expectativa nossa, de trabalhadores do ensino superior, professores e professoras do ensino superior, é de que esse equívoco já esteja corrigido.

Mais tarde, na sessão de 7 de março, ela reproduz esta forma de assistência, mostrando pela recorrência, o peso atribuído ao argumento de nível universitário, mesmo quando em cada debate eram tratados diferentes tópicos. Neste último exemplo, referindo-se a um congresso do sindicato de 
professores universitários, não hesitou em apelar à identificação como um gesto político voltado para os colegas:

gostaria de fazer uma saudação especial pela realização (...) do $25^{\circ}$ Congresso do Andes, (...) porque lecionei durante 26 anos na Universidade Federal de Mato Grosso (...). Com certeza, os participantes do XXVI Congresso do Andes têm na pessoa desta Senadora, que é Senadora temporariamente, mas já ministrou 26 anos de aulas em uma universidade federal, a nossa Universidade Federal de Mato Grosso, alguém que luta, em todas as trincheiras, na defesa do ensino superior público, de boa qualidade, laico e democrático (...).

Com esta intervenção, não só sublinha repetidamente o seu estatuto como professora universitária, mas também se dirige a seus "colegas da universidade", mostrando sua relevância como um setor social ao que pretende representar.

Mas essa posição pode ter nuanças. Na sessão plenária de 30 de janeiro, um senador da oposição se reconhece como produto da universidade, mas destaca o declínio de determinadas instâncias que a conformam, dizendo:

Somos testemunhas vivas da universidade pública, porque cursamos a universidade pública, nossas faculdades pertenceram a universidades federais. $\mathrm{E}$ tanto $\mathrm{V}$. $\mathrm{Ex}^{\mathrm{a}}$ como eu podemos testemunhar isso. Hoje o professor universitário público tem até vergonha de dizer que exerce essa profissão, porque seu salário é medíocre e realmente envergonha esses profissionais, que são peças fundamentais para o processo de desenvolvimento do País, mediante a educação.

Nessa intervenção se faz referência, em primeiro lugar, à passagem pela universidade, utilizando a primeira pessoa do plural quando o parlamentar se refere em seu discurso aos seus colegas. Mas também mencionou a crise da universidade, sem dúvida, à luz da extensa greve de professores. A tentação do discurso da oposição ao usar esse argumento para atacar um dos pilares de legitimação do partido no poder, ou seja, a política de expansão do ensino superior, com a criação de novas universidades, é tão forte como para fazer um apelo a um passado mais glorioso. Portanto, continua o seu discurso afirmando que

os professores de Medicina que chamávamos de medalhões, famosos e bem preparados, faziam questão de ser professores universitários, sentiam-se honrados e orgulhosos de serem professores universitários. Na época em que cursei a Faculdade 
de Medicina, não me lembro de, durante os seis anos de curso, ter um dia voltado para casa mais cedo sequer por ter faltado algum professor. Essa lembrança faz com que nós, hoje, nos sintamos tristes com essa decadência.

Outro senador opositor respondeu nesses termos:

Hoje V. Ex ${ }^{a}$ vem aqui em defesa do ensino público, em defesa dos professores, da valorização do mestre da escola pública e da universidade pública. V. Ex a é mais novo do que eu, V. Ex a colou grau em medicina e eu colei grau em direito, mas eu sei o nome de todos os professores que tive na Faculdade Nacional em Direito da Universidade do Brasil e me formei em 1959, como tenho certeza que V. Ex ${ }^{a}$ se recorda de todos os seus mestres. Hoje o aluno vai para a escola pública e não sabe nem o nome do seu professor. O professor universitário, hoje, infelizmente, não está tendo o mérito que deveria ter, recebe ínfimo salário, não tem condições de trabalho, a universidade pública está indo de mal a pior.

Em ambos os casos, trata-se de um médico e de um advogado, que se orgulham de sua condição de universitários, e do que era a universidade pela qual eles passaram, com seus professores, todos memoráveis, em suas palavras. Apesar destas intervenções, as expressões de orgulho sobre o presente da universidade, com o desenvolvimento da ciência e da tecnologia, a produção de doutores e a extensão universitária, predominam claramente, mostrando o poder simbólico do tema.

Os deputados também fazem demonstrações constantes da importância de terem passado pelo universidade para suas carreiras pessoais.

Na sessão de 16 de janeiro, um deputado (que está defendendo a criação de uma nova universidade) relata a origem de sua vida política desta maneira: "Fiz política secundarista, universitária, profissional, sindical e partidária", mostrando que a passagem pela universidade também pode ser uma chave da formação e exercício político. O mesmo detecta-se na seguinte intervenção: "Iniciei a carreira política como Vereador na cidade de Taubaté, quando ainda era estudante e presidente do Diretório Acadêmico da Faculdade de Direito da Universidade de Taubaté" (sessão de 7 de junho). Em ambas as expressões, trata-se de representantes que abordaram em paralelo ambos os campos (a política e a universitária).

Outro deputado, também no momento de propor uma nova universidade, disse em 9 de fevereiro: “a minha geração, hoje por volta dos 50 anos de ida- 
de, ainda foi privilegiada, porque durante toda a sua formação educacional, desde a creche até a universidade - que é o meu caso -, sempre pôde contar com ensino público de qualidade". Esta intervenção combina a ideia de que a universidade pública é de qualidade (ou foi) e é um privilégio, ainda sem deixar de mencionar que provém de alguém que é universitário.

Ser universitário é um privilégio e confere prestígio $^{18}$. Algumas das intervenções dos deputados nos fazem perceber que existe um senso de importância associado ao exercício de certas profissões universitárias. $\mathrm{Na}$ sessão de 15 de março, um deputado expressa: "Não deixei de ser médico e professor para ter vergonha do meu mandato. Ao contrário, quero ter, e tenho, orgulho de ser Deputado e Político". É claro que o seu argumento é que, se ele abandonou a posição de privilégio como médico e professor, não o estava fazendo para ser deputado e político desacreditado, mas para sustentar sua reputação pela carreira política. A mesma opinião encontramos em uma deputada que tem orgulho de ter estudado direito (sessão de 7 de junho) ("Homenageio a ilustre jurista não apenas como Parlamentar e bacharela em Direito que me orgulho de ser, mas principalmente como cidadã brasileira").

Há uma abundância de deputados que mencionam as condições familiares adversas que tiveram de suportar para entrar na universidade:

Esta data é histórica. A partir de amanhã, nessas 12 cidades, no sul e no norte do Rio Grande do Sul, as famílias dos trabalhadores resgatarão um sonho de décadas: dar essa oportunidade a milhares e milhares de jovens de diferentes gerações que não a tiveram. Digo isso de cadeira, porque sou filho de professora estadual; meu pai era funcionário público de nível médio do DAHER e apenas tive a chance de cursar uma universidade porque nasci em Santa Maria. A primeira cidade, fora das capitais do Brasil, a sediar uma universidade pública. (sessão de 20 de março)

ou também: "De 8 irmãos que somos, só eu e outro ingressamos na universidade. Foi quando ainda cursava Agronomia na Universidade Federal

18 É verdade que o prestígio provém do saber associado a ser um universitário, e a posse de um diploma sem possuir conhecimentos é denunciada em uma intervenção crítica às universidades privadas, na sessão de 19 de janeiro, onde se lê: "E vai para uma universidade privada, em que muitas vezes a qualidade é tão deficiente que ele, embora tenha um título para ostentar, não obtém o conhecimento necessário para enfrentar em igualdade de condições outros profissionais". 
da Paraíba, em 1980, que começou a minha ligação com o Partido" (sessão de 3 de maio), ou mesmo que não conseguiu superar essas limitações: "Infelizmente, os pobres - essa a minha origem, pois sou filho de lavadeira e de servente - não tiveram a sorte de o meu querido Estado ter sido contemplado com universidade como a de Brasília" (sessão do 15 de maio, na qual se discute a reforma universitária).

Nessas intervenções, é claro que o acesso à universidade para os setores mais baixos, ou provenientes de áreas distantes dos grandes centros urbanos, é algo incomum ou impossível. Mas também, que é um sonho e uma fonte de orgulho poder superar essas condições adversas, o que remete a potência do relato meritocrático associado à universidade. A consciência das baixas taxas de acesso ao ensino superior se reflete frequentemente, como pode ser visto nos seguintes exemplos encontrados nos discursos dos deputados: na sessão de 23 de janeiro, um deles observou essa diferença dizendo "Vale lembrar que apenas 10\% dos jovens brasileiros entre 18 e 24 anos matriculam-se no nível superior, índice inferior ao de países como a Argentina, que tem $40 \%$ dos seus jovens nessa faixa etária na universidade".

Em uma reunião posterior ao 23 de maio eles retornam a esse tema da seguinte forma: "Apesar do aumento da oferta de cursos superiores, apenas $9 \%$ dos jovens de 18 a 24 anos de idade estão na faculdade. No Chile, são 27\% dos jovens; $39 \%$ na Argentina; $62 \%$ no Canadá; e $80 \%$ nos EUA. Em Estados como a Bahia, não chega a $4 \%$ o índice de jovens no ensino superior".

Em 8 de junho, um outro deputado argumenta, de modo semelhante:

Tomando como indicador a taxa bruta de matrícula na educação superior, que relaciona o número de matriculados, independentemente da faixa etária, com o número de jovens na faixa etária própria, já apresentada, a situação do Brasil é também amplamente desfavorável quando comparada com a de outros países da América Latina. Se a taxa brasileira é de $21 \%$, na Argentina ela alcança $60 \%$, no Chile, $45 \%$, na Venezuela, em torno de $40 \%$. Na Bolívia equivale a $39 \%$.

Assim, encontramos nos discursos uma combinação de pontos de vista sobre o prestígio associado à universidade e à visão dela como um destino preferencial, privilegiado, para poucos que, sem dúvida, aumentam sua importância política. 


\section{A universidade como lugar de socialização dos setores dominantes}

Obviamente, nem tudo é reduzido ao papel legitimador que a universidade pode ter em um contexto no qual o saber, ou mais precisamente, o poder de apresentar credenciais que acreditam supostos conhecimentos, encontra altos níveis de reconhecimento, capazes de traduzirem-se no campo político.

Nos discursos de parlamentares, temos a possibilidade de desvelar indícios da forma em que se entrecruzam o mundo da universidade com o do poder.

Os senadores, em grande parte, são universitários, mantêm vínculos com a universidade, como professores, doutores e autoridades acadêmicas. Nesse sentido, o significado da figura dos reitores das universidades é evidente, e há muitos casos que mostram as interações entre os senadores e os reitores. Mas também é claro que a atenção dada à universidade como um ator social importante, que é ouvido, e cuja opinião é respeitada, está relacionado à ideia de que os acadêmicos estão muito perto dos parlamentares.

Há muitos exemplos que mostram como o convívio em atividades diárias entre esses grupos é constante. Um senador, na sessão de 10 de fevereiro sobre a importância da TV Senado, diz que ele foi reconhecido na saída da missa do domingo por suas aparições na televisão. Quem são aqueles que vão à missa com o senador? "Ao sair, encontrei quatro pessoas - um médico, um ex-deputado do Pará, um corretor e um professor universitário - que me perguntaram: 'O senhor é o Senador?' Quer dizer, a TV Senado nos dá visibilidade”.

Exemplo curioso, que mostra a proximidade de senadores, representantes, profissionais universitários e professores universitarios, reunidos em contextos sociais comuns, em que interagem compartilhando estilos de vida, práticas, posições sociais... o que raramente acontece com outros setores, como referenda um senador na mesma sessão, dizendo que o melhor legado que poderia deixar o governo Lula seria "garantir que pobres e ricos possam estudar em escolas equivalentes no Brasil. Nem coloquei "nas mesmas escolas", porque sei como há uma reação do piso superior da pirâmide social ao piso inferior". Claramente, vemos nesses termos a ruptura social profunda, bem como a sugestão de que os universitários ficariam do lado dos setores dominantes, embora em alguns casos possam ser os primos pobres e marginais, mas não menos prestigiados ${ }^{19}$.

9 Neste ponto podemos lembrar as conclusões de Lipset (1977) para analisar o papel dos intelectuais nos Estados Unidos. Querendo saber por que eles tendem a ser de esquerda, conclui que, embora eles se sintam negligenciados e desprezados, seu "status real" como intelectuais os coloca em "um lugar bastante alto", de modo que "aqueles que mantêm atividades intelectuais têm nos Estados Unidos, quase o mesmo prestígio como empresários, banqueiros e importantes dirigentes de em- 
Os senadores convivem com o ambiente universitário, e até mesmo fazem esforços para destacar essa proximidade, como mostra a intervenção de um senador na sessão de 10 de agosto, na qual ele narra suas relações com o mundo intelectual e da produção de livros: "Eu gostaria, Sra Presidente, de anunciar que foi publicado, neste mês, o livro Políticas públicas e a realização dos direitos sociais, da Professora (...). Tive a honra de ser convidado para escrever o prefácio desse livro". Esse discurso é seguido por outro parlamentar, que talvez por a necessidade de não ficar atrás, tomou a palavra para dizer:

desejo registrar o lançamento (...) ocorrido ontem de um livro de enorme oportunidade intitulado Reforma política no Brasil (...). Eu gostaria de lembrar que, durante muito tempo, a Universidade editou a Revista de Estudos Políticos, que foi dirigida pelo Professor Orlando Carvalho, falecido já, infelizmente, um grande doutrinador neste campo, com quem aprendi muitas e valiosas lições.

É claro que, além da necessidade de mostrar a sua participação no evento, o senador apresenta uma grande familiaridade com as questões acadêmicas relativas ao departamento de ciência política da Universidade de Minas Gerais e sua interação com muitos dos membros dessa área.

A passagem pela Universidade também é apresentada como um sinal de status. Nesse sentido, um senador disse na sessão de 21 de fevereiro, contando que ele decidiu cursar o mestrado na Universidade Federal do Estado:

Fui provocado pela minha esposa, que disse: "Você está fazendo esse mestrado porque quer mesmo seguir carreira acadêmica, ou porque você quer aparecer na carreira política?". Eu passei no mestrado, Sr. Presidente, sinto-me duplamente desafiado. Acho que nós, aqui do Senado Federal, temos que contribuir urgentemente para que o ensino no Brasil seja de fato uma prática da ciência, e não uma espécie de instituto do diploma para status quo, status social, que as pessoas vendam essa imagem.

Sem dúvida, esta intervenção é muito rica porque reconhece o lugar da universidade na geração de capital simbólico e seu valor na arena política.

presas", (Lipset, 1977, p. 311). Assim, Lipset argumenta que os intelectuais (incluindo na categoria os universitarios) têm um "status" semelhante aos dos setores dominantes, embora geralmente eles não se autopercebam como tais. 
Há também muitos exemplos de laços familiares com a universidade. Os representantes são universitários, bem como suas famílias. Uma senadora na sessão de 10 de agosto, depois de ter sido questionada pela imprensa do seu Estado, faz uma descrição de sua família, apresentando-a desta maneira:

Tenho quatro filhos: uma médica, um advogado, uma psicóloga e um engenheiro. Os quatro, Senadora, felizmente - alguns até dizem que é um defeito que eles têm - são extremamente estudiosos. Alguém que chegue a Mato Grosso e peça referência, em uma dessas categorias, de um filho ou de uma filha minha, tem as melhores referências. Não vou falar - ali há alguém fazendo sinal de positivo - porque sou suspeita. Os quatro são pós-graduados em nível de mestrado, dois têm doutorado. Um deles já foi professor da PUC de São Paulo; outra é professora concursada da Universidade Federal de Mato Grosso.

$\mathrm{Na}$ intervenção é muito claro, por um lado, que as famílias dos representantes costumam ser universitárias como eles, mas também, que o ser universitário, e particularmente um universitário bem sucedido com determinada trajetória, com pós-graduação ou exercendo o magistério superior, ou acadêmico reconhecido, é um antecedente, uma referência positiva à que apela diretamente, sem eufemismos. A taxa de conversão do capital simbólico universitário em capital político é, portanto, favorável à conclusão dessa transação e, por conseguinte, é fácil revelar os esforços dos senadores para destacar sua formação acadêmica e suas qualificações, a fim de usá-las como elementos de distinção política.

\section{Elites e universidade}

Uma parcela importante dos parlamentares que estamos estudando aqui é geralmente apresentada como parte de uma minoria privilegiada, as elites, com a responsabilidade de levar adiante o destino do país. Isso fica claro a partir da intervenção de um representante na sessão do 18 de Janeiro:

... avanços em que as elites - e nós, indiscutivelmente, compomos a elite política deste país - começam a compreender que elas também precisam ter gestos de desprendimento num país em que milhões ainda passam fome, em que milhões não têm emprego, em que milhões não têm casa, em que milhões não têm o mínimo necessário para o atendimento de suas necessidades de vida. 
O mesmo percebemos na sessão de 7 de março, quando um deputado disse: "O Brasil precisa de muitas transformações e espera bastante de suas elites. E esse é o papel dos políticos".

Envolvido no mesmo registro, encontramos outro discurso, de 9 de maio, dizendo: "temos de compreender que milhares de pessoas não sabem ler e que as elites mandam no país".

Mas o acesso ao ensino universitário também é tradicionalmente visto como um privilégio das elites, que, sem dúvida, reforça a parceria entre os dois campos. "Até há poucas décadas ainda se percebia a educação como privilégio das elites e marca da classe social", diz um deputado na sessão de 20 de abril.

Outro afirma que esta situação não mudou muito, pelo menos nas universidades públicas, que são considerados de melhor qualidade, "e o aluno hoje é obrigado a seguir a uma universidade que, se pública, se torna cada dia mais elitista e segregadora numa atuação que afronta a todo bom senso e ponderação" (sessão de 2 de maio).

Em 22 de maio, outra intervenção percebe como as elites econômicas usam as universidades públicas:

A elite paga o seu plano de saúde, a sua escola privada - muitas vezes seus filhos cursam universidades públicas - e se fecha em condomínios de luxo, pois não quer olhar para o que acontece lá fora. Basta abrir a janela do carro ou às vezes a do helicóptero para saber o que se passa lá embaixo.

A universidade é, então, vista como um privilégio, de acesso restrito para a maioria, ocupado em grande parte pelos setores sociais mais privilegiados, e formando líderes políticos e econômicos:

(...) a Faculdade já soma mais de 5 mil profissionais capacitados para o mercado, atuando, inclusive, nas mais altas Cortes jurídicas do país ou em áreas afins, como a política (...). O reconhecimento da comunidade foi obtido, ainda, graças a comprovações da qualidade do ensino oferecido. Um exemplo são os elevados índices de aprovação no Exame da Ordem dos Advogados no Brasil e nos concursos públicos,

diz um deputado em referência aos méritos de uma universidade do seu Estado (3 de maio), destacando tanto a consideração que alcançou a universidade "na comunidade", após o sucesso dos seus graduados, incluindo a 
sua integração no mundo jurídico e político, mostrando claramente o peso do precedente universitário para o acesso ao campo político.

\section{A formação acadêmico-universitária como eixo da legitimação política nos discursos}

A seguinte questão tem sido central para os debates das duas Casas do Congresso: a importância da formação acadêmica dos líderes que chegam à cúpula do poder.

Nesse sentido, as imagens de Fernando Henrique Cardoso (FHC) e Luiz Inácio Lula da Silva são uma expressão importante de visões opostas nesta área.

O primeiro foi apresentado como um expoente do mundo universitário, como expressão clara da conversão do capital simbólico da universidade em capital político, a transferência de prestígio acadêmico ao político, produto de anos de acumulação no primeiro campo e um forte reconhecimento disso no terreno político, algo que se inscrevia com facilidade na matriz de legitimidade predominante e desejável na tradição política brasileira, na qual o peso histórico da ideia de elite e da valorização da universidade, produziu uma ampla parceria entre os dois ${ }^{20}$.

É por isso que o surgimento de Lula nesse cenário foi definitivamente uma ruptura, pois conseguiu construir a sua legitimidade por outra via, conformando-se como uma antítese a FHC. Com seu passado não universitário, disputou o poder durante anos, incapaz de mudar a raiz de legitimação da estrutura meritocrática como é evidenciado pelas suas derrotas nas eleições presidenciais de 1989, 1994 e 1998, em que as deficiências de Lula "o trabalhador" costumavam se manifestar em uma acusação repetida como "analfabeto". À luz dos resultados eleitorais até 2002, o argumento parece ter conseguido deslegitimar o sindicalista não universitário diante do elevado acadêmico.

Apenas quando o candidato foi capaz de reciclar essa fraqueza como força, como um elemento distintivo que lhe facilitou se mostrar como o oposto a FHC, conseguiu aceder à presidência.

Mas, apesar da vitória, o peso dessa questão seguiu presente nos discursos no Parlamento. Isso é evidente na sessão do Senado de 23 de fevereiro,

20 Sader (1999) não hesita em caracterizar Fernando Henrique Cardoso como o principal teórico brasileiro da matriz conservadora, responsável pela modernização desse discurso sobre a base de seu prestígio acadêmico. 
quando se produz uma ampla troca de opiniões entre oposição e oficialismo em relação às declarações do então presidente sobre um fundo de desenvolvimento para a educação. Nesse contexto, um senador diz:

Portanto, Sua Excelência (referindo-se ao presidente), que sabíamos autoritário e ávido por usurpar as competências constitucionais do Congresso Nacional, agora dá uma clara demonstração de que não sabe nem o que é o Fundeb. Não precisa ter feito curso superior para saber que o processo legislativo não funciona assim. Aliás, ontem o presidente se disse arrependido de não ter cursado a universidade. Apesar de ter passado mais de vinte anos só fazendo política, não investiu um dia sequer em sua formação pessoal. Outros, como o Deputado Vicentinho, que era um líder sindical como Lula, durante o período em que foi líder sindical estudou e se formou. O presidente Lula não dedicou um só dia aos estudos, inclusive de vez em quando dá declarações como se a educação não fosse importante.

Novamente, como nas campanhas eleitorais, a desqualificação de Lula se focava em que ele não estudou, que não tinha ido para a universidade.

Um senador do partido governista respondeu, tentando contextualizar o momento histórico, como forma de justificar o que, em última instância, é reconhecida como uma falha do ex-presidente: não ser universitário. Em seu discurso, declarou:

É rapidinho, é sobre essa história de estudar ou não. Nessa época, como eu já estava próximo ao presidente Lula e à classe sindicalista que formou a CUT nacional, sabia que havia uma certa maneira de ver as coisas. Nada era dito, nada era publicado, mas havia o entendimento de que quem era liderança popular, liderança operária, camponesa ou coisa parecida não precisava estudar. Isso era quase cultural. Só tempos depois é que o Vicentinho se propôs o desafio de fazer faculdade - eu peguei o embalo da provocação dele, me parece que foi 1997, e também resolvi retomar os estudos. Reitero, portanto, que não era incomum ouvir que o líder operário metalúrgico bom era aquele que não perdia as suas raízes. Lembro-me, inclusive, de Vicentinho haver reclamado disso quando decidiu estudar inglês - disseram: "Mas para que operário vai ter de estudar inglês"?". Faço essas observações para dizer a V. Ex ${ }^{\mathrm{a}}$ que, quanto a isso, é preciso levar em conta o momento em que vivíamos e a situação como é hoje.

É interessante ver que na defesa do então presidente há um apelo a circunstâncias históricas, mas, ao mesmo tempo, um reconhecimento de que 
já não é assim no presente, e que o próprio senador governista precisa se diferenciar, afirmando que ele sim estudou.

Assim, a resposta da oposição destaca essa diferença, argumentando:

É quase inacreditável isso, mas, como é V. Ex ${ }^{a}$ que está dizendo, eu acredito. De qualquer forma, tiramos disso uma lição: V. Exa é mais ponderado do que o presidente Lula, porque mesmo nesse ambiente negativo, V. Ex ${ }^{a}$ e o Vicentinho conseguiram verificar que estudar era bom, para líderes sindicais e para os outros (...). O que gostaríamos do presidente Lula, já que ele não estudou, é que ele lembrasse que é um exemplo para a Nação - não vamos discutir se ele é bom ou ruim; eu, por exemplo, penso que ele é um mau presidente, mas respeito o senador Sibá Machado se considerar que ele é bom. Eu só gostaria de que ele, quando fosse se dirigir à população falando sobre educação, mostrasse a convicção de que, se tivesse estudado mais, seria um Presidente melhor. É este o exemplo que deve dar às pessoas: mostrar que as pessoas que estudam podem se sair melhor na vida, sem acreditar que, porque ele não estudou e se saiu bem, ninguém precisa estudar (...) se ele tivesse estudado, ele seria melhor.

Claramente, a mensagem é que Lula não poderia ser um bom presidente, porque ele não tinha estudado.

O mesmo pode ser visto na sessão do 30 de janeiro, quando um senador assume o problema nos seguintes termos:

E eles fizeram um livro, que o Lula não vai ler: Reinventando o governo (...). Então, faço essa síntese para o Lula refletir. Ele não vai ler o livro. Ele não gosta de ler (...). E o presidente Lula, encaminhado pela ignorância que lhe é peculiar, de chofre, no ato, deu muito emprego, mas para companheiros derrotados do seu Partido.

A forte desqualificação do Lula é centrada em um ataque contra o que consideram sua ignorância, que é expressa em uma alegada falta de hábito de leitura.

Com argumentos semelhantes, outro senador, na mesma sessão, novamente se refere ao assunto, mostrando que o argumento do conhecimento como ferramenta de desqualificação tem uso difundido entre os representantes brasileiros. Ele diz:

Ele não sabe, realmente, o que é equidade e não sabe o que é o ensino universitário, até porque tinha horror a esse ensino, tanto que não quis nunca cursar uma univer- 
sidade ou mesmo o ensino fundamental. Desse modo, falta-lhe autoridade pessoal para discutir ensino. E, portanto, a maldade que ele faz aos professores é porque ele nunca teve professor, não gostava de estudar, mesmo depois que teve oportunidade, quando o Partido lhe pagava uma pensão boa.

O ponto é que o fato de não saber, não sendo um universitario, mina a autoridade para resolver certos problemas. Isto é o que está presente nos discursos que desqualificam os representantes não-universitários. Assim, um senador na sessão de 16 de fevereiro não hesita em afirmar que:

E V. Ex a é professor. Não conheço, na época contemporânea, nenhum presidente melhor do que o professor e ex-presidente do Chile, Ricardo Lagos ${ }^{21}$, que foi Ministro

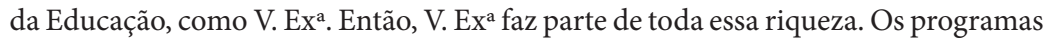
de $\mathrm{V}$. Ex ${ }^{\mathrm{a}}$ são ricos porque têm como base a educação. V. Ex ${ }^{\mathrm{a}}$ tem essa experiência da democracia, em que há uma esperança de alternância do poder. Penso que V. Exa deve entrar com essa perspectiva de vencer. Se chegar à presidência, a vitória é da educação. O seu companheiro Lagos foi professor e ex-Ministro da Educação. Hoje, todos nós somos orgulhosos da civilização chilena.

Contra o admirado professor, a desqualificação de quem não tem diplomas, é exacerbada na sessão de 16 de agosto, quando um outro senador refere-se "à maldade do Doutor Lula. O Doutor Lula não suporta os baianos", chamando-o de "doutor" com a clara intenção de enfatizar a sua falta de qualificações acadêmicas.

Dentro dessa lógica é que um senador do governo detecta a necessidade de defender o seu lugar (sessão de 7 de março), declarando:

Sr. presidente, venho do Estado de São Paulo e me formei na mesma universidade que o ex-presidente Fernando Henrique Cardoso: a Universidade de São Paulo, a USP. Fiz mestrado e doutorado na Universidade de Campinas, a mesma universidade do ex-ministro Paulo Renato Souza. Por sinal, trabalhávamos juntos na mesma sala, já em 1977, pesquisando Economia do Trabalho.

Sublinhar que compartilham a mesma formação, o mesmo passado acadêmico na universidade, parece ser a única maneira de dar a autoridade de

${ }^{21}$ Lembre-se que o caso de Lagos, no Chile, tem alguns pontos de contato com o FHC no Brasil, em sua importante carreira acadêmica (advogado, economista, professor universitário nos EUA e Chile) e sua posterior passagem ao campo político. 
saber ao discurso dos partidários do governo, que devem suportar o estigma de "não ser universitários" permanentemente retomado pela oposição. Para este senador, é necessário esclarecer que ele possui a mesma formação acadêmica que os adversários, e que lhes responde desse lugar de saber e prestígio.

\section{Lula como a antielite}

Se na análise dos discursos dos senadores já percebemos o modo como eles tratam a oposição entre FHC e Lula em relação aos seus antecedentes na universidade, também identificam-se muitos discursos, entre os deputados, em que se referem a este assunto, mostrando a relevância que teve e ainda tem o tema.

Em 30 de janeiro, um deputado afirmou que Lula teria feito uma universidade, "a do sofrimento": "O presidente não teve uma universidade federal, mas teve a universidade do sofrimento, do pau-de-arara, da metalurgia, em São Paulo, dos sindicatos, do combate à violência”.

Outro manifesta, diferenciando-se de seu predecessor, o papel da "universidade do povo" na formação do presidente, quando na sessão de 16 de fevereiro diz:

não há como negarmos ao povo brasileiro que existe um aspecto talvez menor, mais subjetivo, mas verdadeiro. Fernando Henrique, um professor, um homem da academia, um homem que fala línguas, que viaja o mundo e em cada país esnoba um pouco com as línguas que fala, parece ter inveja de um metalúrgico. Fernando Henrique Cardoso ficou à frente do Governo do País por 8 anos e foi suplantado por um homem que tem o $4^{\circ}$ ano primário, fala apenas o português e, todos sabemos, em vários momentos se atrapalha com a gramática. Mas é um operário que veio das lutas sociais, foi formado na universidade do povo, sintoniza com $90 \%$ do povo brasileiro. Nunca teve diploma. O primeiro diploma do presidente Lula, que ele exibiu ao povo brasileiro chorando, foi o de Presidente da República.

Curiosamente, em ambos os discursos proferidos por deputados do partido no poder, há um reconhecimento de que o presidente não é universitário, mas afirmam que ele conheceu a universidade "do sofrimento", "do povo" ... como se fosse necessário marcar que é preciso ter feito alguma universidade para chegar ao ponto culminante do poder ${ }^{22}$.

22 O mesmo foi dito em uma intervenção de 23 de fevereiro, referida ao então vice-presidente José Alencar, um empresário liberal, líder da indústria, que acompanhou o presidente Lula em seus dois mandatos. 
Claramente, a questão tem um lugar importante, que o ex-presidente Lula enfatizou, talvez porque ela estava no cruzamento das duas tradições sobre a representação política que mencionamos no início deste trabalho: a representação elitista e a representação "espelho"23. O esforço do partido no poder para usar argumentos da segunda tradição é evidente na intervenção do deputado, quando ele argumenta que o presidente sem formação universitária está "em sintonia com $90 \%$ do povo". Mas, apesar disso, não conseguiu se desprender de todo o peso tradicional da primeira forma de legitimação, que em grande parte apoiada pela oposição, ainda desempenha um papel significativo. Portanto, a importância que o governo atribui à universidade é apresentada como uma compensação pela falta de universidade do presidente, e ressaltou isso em termos comparativos, como faz o seguinte discurso de 3 de abril:

já ao tomar posse, o presidente Lula foi marcante quando, emocionado, disse: " $\mathrm{Eu}$, que não tive oportunidade de ter um diploma, agora recebo o diploma mais importante do Brasil". Por que o presidente reagiu daquela forma? Porque não conseguiu cursar uma universidade - e esse era o maior argumento que os preconceituosos tinham contra o presidente Lula. Embora eu tenha tido a felicidade de terminar o meu curso de Direito - o que não foi fácil -, sei que as pessoas, muitas vezes, só analisam as outras pelo grau de conhecimento e de estudo que têm. Vamos comparar: o que fez Fernando Henrique Cardoso, doutor honoris causa, detentor de vários títulos de diversas universidades, pelo ensino fundamental? Ele o destruiu (...). Só entra na faculdade aquele que estudou em escola de melhor qualidade - lamentavelmente, a escola privada. $\mathrm{Na}$ hora do concurso público, ocorre o mesmo. De novo, o pobre é marginalizado (...). Quantas vagas o doutor honoris causa Fernando Henrique Cardoso e o PSDB criaram no ensino superior? Nenhuma. E Lula, o operário, quantas criou? Já votamos a criação de 11 universidades públicas em seu Governo (...) e 112 mil vagas no ano passado e 150 mil neste no PROUNI. Agora, ao entrarem na universidade, jovens da periferia, negros e índios terão igual oportunidade de se tornar doutores. Essa é a grande diferença. E ela incomoda, porque o garoto vai sair da favela e virar doutor. Não estranhem, telespectadores, quando, em breve, virem jovens negros serem doutores neste país (...) E, é bom lembrar, foi um operário quem fez isso.

Sobre ele, um deputado diz: "Poucos brasileiros têm como ele a percepção do que acontece no Brasil e no mundo, já que frequentou a grande universidade da vida, do trabalho e da luta" reproduzindo a ideia de que "a universidade da vida"é importante.

${ }^{23}$ Entende-se por esse termo a postura que considera que os representantes devem ser um reflexo do povo, com uma composição semelhante à do mesmo. Lembre-se que o ataque de Madison contra algumas das propostas dos antifederalistas está ligado a esse problema. 
Fica claro, a partir da leitura dessa intervenção, o peso de ser um universitário na formação de preconceitos. Nos termos que estamos utilizando neste trabalho, o deputado diz explicitamente que o fato de não ser universitário é um problema para a acumulação de capital simbólico pessoal.

Não só há a referência do que o acesso à universidade pode significar progresso econômico, abrindo a porta para empregos mais qualificados e melhor remuneração; a ênfase está na mudança que se origina na consideração social, e é expressa na possibilidade de se tornar "doutor".

Este é o grande problema que relaciona à universidade com os políticos que precisam maximizar a sua legitimidade (ainda mais se eles tem uma eleição) e, portanto, eles não devem perder nenhuma fonte produtiva de prestígio como é a de "ser doutores".

$\mathrm{O}$ antecedente universitário é considerado um crédito. Não possuí-lo, como salienta um deputado do governo na sessão do 21 de junho, pode anunciar todos os tipos de incertezas. Em suas palavras: "Na última campanha eleitoral para Presidente da República, muitos comentários pesados, preconceituosos, amedrontadores, até terroristas, ouvimos contra o Presidente Lula. Diziam que (...). Lula era incapaz de governar (...). Afinal de contas, tratava-se de um operário, de migrante nordestino que não cursou a universidade, o que não é nenhum demérito. Sabemos por que muitos não puderam cursar a universidade neste país (...)".

Portanto, para essa consciência de que se deve ser universitário, é que ele se sente obrigado a argumentar que não é um demérito não ser, e que em grande parte essa falta é o produto de um país onde muitos não tiveram acesso ao ensino universitário (note que ele não diz, como os críticos afirmam, que Lula não quis estudar, mas que ele não conseguiu).

\section{Algumas conclusões}

A primeira coisa que podemos concluir é que em ambas as Casas do Congresso encontramos uma representação que não pode ser considerada como um "espelho" da cidadania, mas expressa uma concepção aristocrática (meritocrática) da representação política, em que o perfil de universitário parece desempenhar um papel significativo pela sobrerrepresentação dos universitários.

A análise dos discursos dos deputados e senadores nas sessões de seus respectivos corpos mostra que o mito da universidade tem saúde e consi- 
derável força, dadas as constantes manifestações de alto valor que recebe a mesma por parte dos legisladores.

A universidade brasileira ainda é considerada, nos discursos da maioria dos parlamentares, um santuário do saber, e em muitos casos, uma fonte de orgulho nacional como motor de progresso e desenvolvimento.

Essa crença na qualidade da universidade e no seu reconhecimento social é um antecedente fértil para que o contato entre o político e a universidade seja muito estreito. A isto se lhe poderia agregar que a proximidade social de uma universidade de elite com os tomadores de decisão gera mais afinidades para facilitar o intercâmbio entre os dois universos. Os representantes são majoritariamente universitários, frequentam universidades, mantêm seus laços com elas e os exibem como galardões, como certificações de seu saber e sua respeitabilidade, o que se torna relevante para a instância eleitoral, mas também para obter autorização para tratar certos discursos ou determinados temas.

Tais observações ratificam alguns dos pressupostos que nortearam o nosso trabalho. Primeiro, é compreensível que a educação universitária otimiza as oportunidades de acesso a cargos eletivos de representação política, enquanto a eleição supõe uma seleção, e a universidade é tida como a mais alta instância de formação e é reconhecida como uma fonte de valor.

Ele também permite sustentar que, na medida em que o ensino universitário é prestigiado, pelo menos entre os eleitores e as elites políticas, tal fato garante que ele seja um elemento importante na formação de capital simbólico pessoal dos representantes e, portanto, de capital político.

Isso também acontece se os conhecimentos proporcionados pelo currículo universitário formal são diferentes daqueles exigidos para o exercício do trabalho parlamentar, o que não minimiza a importância de ser universitário. Em muitas discussões que temos salientado, a questão é se há ou não estudado na universidade, ficando para um segundo momento o que tem sido estudado, que tem um efeito posterior sobre a preparação para integrar algumas discussões específicas.

Finalmente, a densidade da relação universidade-parlamento pode ser delimitada pela crise dos pressupostos ideais existentes por detrás de ambas as instituições, embora no caso do Brasil, no período estudado, é a crise do parlamento como instituição que parece prevalecer, incentivando o recurso à universidade como instância que o legitima. Daí se compreende a forte presença das referências à universidade em várias formas em debates par- 
lamentares e uma especial valorização da passagem pela universidade para a carreira política.

\section{Referências bibliográficas}

ABELES, Marc. 2001. Un ethnologue à l'Assemblée. Paris: Odile Jacob.

BOURDIEU, Pierre. 1989. La noblesse d'État: grandes écoles et esprit de corps. Paris: Minuit.

ELSTER, Jon. 1994. "Argumenter y négocier dans deux assemblées constituantes". Revue Française de Science Politique, v. 44, n. 2, p. 187-256.

EULAU, Heinz \& SPRAGUE, John. 1964. Lawyers in politics: a study in professional convergence. New York: The Bobbs Cerril.

FUKAI, Shigeko \& FUKUI, Haruhiro. 1992. "Elite recruitement and political leadership”. Political Science and Politics, v. 25, n. 1, p. 25-36.

GENIEYS, William. 2006. "Nouveaux regards sur les élites du politique". Revue Française de Science Politique, v. 56, n. 1, p. 121-147.

IMAZ, José Luis. 1964. Los que mandan. Buenos Aires: Eudeba.

LEMOS, Leany \& RANINCHESKI, Sonia. 2003. "Carreras políticas en el Senado brasileño: un estudio de las composiciones del pleno y de la comisión de constitución, justicia y ciudadanía en la década de 90". Lateinamerika Analysen, n. 4. Disponível em: http://americo. usal.es/oir/legislatina/papers/Barreiro_Ranincheski.pdf (acessado em $5 / 1 / 12$ ).

LIPSET, Seymour Martin.1977 [1960]. Political man, the social bases of politics. New York: Doubleday.

MADISON, James et al. 1961. The federalist papers. Chicago: Nal Penguin. MARENCO, André \& SERNA, Miguel. 2007. "Por que carreiras políticas na esquerda e na direita não são iguais? Recrutamento legislativo no Brasil, Chile e Uruguai”. Revista Brasileira de Ciências Sociais, v. 22, n. 64, p. 93-113.

MOLINELLI, Guillermo; PALANZA, Valeria \& SIN, Gisela. 1999. Congreso, presidencia y justicia en Argentina. Buenos Aires: Temas.

SADER, Emir. 1999. "Brasil: uma historia de pactos entre elites". In BORON, Atlio (comp.), Tiempos violentos. Buenos Aires: Clacso.

SCHEDLER, Andreas. 2004. "El voto es nuestro, cómo los ciudadanos mexicanos perciben el clientelismo electoral”. Revista Mexicana de Sociología, v. 66, n.1, p. $57-97$. 
TOCQUEVILLE, Alexis de. 1986 [1835]. De la démocratie en Amérique. Paris: Gallimard.

URIARTE, Edurne. 1997. "El análisis de las élites políticas en las democracias". Revista de Estudios Políticos n. 97, p. 97-124.

\section{Resumo}

O presente artigo, realizado no marco de uma pesquisa sobre a relação entre a universidade e o poder legislativo em alguns países da América Latina (particularmente no Brasil e na Argentina), analisa o modo como a passagem pela universidade contribui para a formação do capital político dos deputados e senadores brasileiros, bem como a importância dessa passagem na trajetória dos integrantes do poder legislativo. Para tanto, analisamos os discursos dos parlamentares nas sessões de 2006, procurando as referências que eles mesmos realizam sobre a universidade e sobre suas experiências no terreno acadêmico. $\mathrm{O}$ artigo fornece evidência para sustentar que existe uma forte sobrerrepresentação dos universitários no congresso brasileiro, que a trajetória acadêmica é valorizada no interior das elites parlamentares - o que lhe permite jogar um papel na distribuição do poder interno no congresso -, e que a passagem pela universidade, na medida em que se apresenta como um ativo valorizado e escasso, é um elemento relevante na formação do capital simbólico dos representantes legislativos.

Palavras-chave: Poder Legislativo; universidade; capital político; candidaturas.

\section{Abstract}

This article was written within the framework of a research about the relationship between college education and the Legislative in some Latin American countries (particularly Brazil and Argentina). It examines the way in which college education contributes to increase the political capital of Brazilian deputies and senators as well as the importance of college studies in the career of the members of the Legislative. Therefore, the article examines the speeches of Congress members in 2006 sessions, observing their references to college education and their experiences in the academic field. The article provides evidence to sustain that college graduates are largely overrepresented in Brazilian Congress; that college education is appreciated by parliamentary elites - allowing them to play a role in the distribution of the internal power in Congress; and that such education is a significant element in the making of the symbolic capital of those members.

Key words: Legislative; college; political capital; candidacies.

Recebido em 30 de janeiro de 2012.

Aprovado em 27 de março de 2012. 